\title{
Cultivating Design Thinking in Students through Event Simulation Course
}

\author{
Xuehui Zeng \\ Event Management Department \\ Shanghai Second Polytechnic University (SSPU) \\ Shanghai, China
}

\begin{abstract}
Event industry is facing a big challenge of sustainability. Students of event management will encounter the uncertainties of real world and business problems where many stakeholders are involved. The major purpose of education is to prepare the student for the change and the challenge through learning process. Therefore, it is necessary to incorporate design thinking into the teaching strategy and link to studies done in the field of cognition using abductive reasoning in addition to deductive and inductive skills. The objective of this paper is to discuss how to cultivate design thinking in students through Event Simulation Course. First, students are asked to do the research and report of what they have observed in 19th IE expo China 2018 about non-green problems and challenges from different perspective of stakeholders. And then they are required to plan a team project developing a possible solution for a 2028 Green Event using design thinking process and event model canvas tools. Research shows that design thinking as a teachinglearning methodology cultivates the students in three aspects: cognition, affection and interpersonal communication skills. The findings of the paper will help the facilitators to design a successful collaborative learning experience for the students in order to achieve the goal of learner outcome.
\end{abstract}

Keywords-teaching methodology; design thinking; learning experience

\section{INTRODUCTION}

19th IE expo China 2018, gathering of worldwide industry leaders, is an Asia's leading trade show for environmental technology solutions held at Shanghai New International Expo Centre (SNIEC) on May 3-5. The 2018 show is expected to welcome around 1,800 exhibitors in the fields of water, waste, air and soil management. Meanwhile, international and regional pavilions are presented by organizations from 15 countries in North America, Europe and Asia. Those selected solution providers will bring the most cutting-edge and promising environmental technologies with years' international experiences, which help to tackle current environmental pollution issues. The Organizers of the event are Chinese Society for Environmental Science, China Environment Chamber of Commerce, China Resource Recycling Association, Messen Muenchen and Messe Muenchen Zhongmao co., ltd. 70 students of event department,

This research was supported by the Tourism Management Discipline Research Program funded by Shanghai Polytechnic University, P.R. China (Grant NO. XXKPY1607).
SSPU are organized by the department to attend the show and provide on-site services as volunteers mainly in the positions such as organizer's office, check-in counter, news center, release center, information center, conference center, group audience reception, lottery draw station, gift exchange desk, etc. The 3-day internship experience is the preparation for the practical course Event Simulation held in 4-week summer semester from June 19 to July 19. During this period, Prof. Dr. Yen, Dean of Hospitality Tourism and Event Department, San Jose State University, USA is invited to give lecture as guest professor and we Chinese act as co-teacher for the whole teaching implementation.

\section{Methodology}

Event Simulation course is design for the third-year students and prepares them for practical skill in the real world after graduation. Event Simulation course is planned for two sections. In the first section, students are working on the exhibition venue as a volunteer, therefore, we prepared questionnaire for their interview to the selected stakeholders and checklist for the observation of green and non-green elements in the venue. These are the two documents for the students to do the research before the second section of the course.

\section{A. Questionnaire Development for The Interview to The Selected Stakeholders}

Design thinking is the mental processes used by designer to design objects, services or systems for the end-user. Designers work on a "projected" basis around complicated problems.[3]Therefore the first important concept for design thinking is the end-user or the stakeholder. In order to guide the student to better understand the needs and the expectations of the stakeholders of 19th IE expo China 2018, a questionnaire is designed for the students to have an interview with selected stakeholders, for example, the organizer, coorganizer and the service provider. 
TABLE I. QUESTIONNAIRE FOR THE INTER VIEW TO THE SELECTED STAKEHOLDERS

\begin{tabular}{|c|l|}
\hline Stakeholders & \multicolumn{1}{c|}{ Questions } \\
\hline Organizer: & $\begin{array}{l}\text { 1. Why hold IE expo China 2018? } \\
\text { 2. What are the biggest difficulties and challenges in hosting the expo? }\end{array}$ \\
\begin{tabular}{|c|l|} 
Chinese Society for \\
Environmental Science
\end{tabular} & $\begin{array}{l}\text { 3. What is the expected goal of China environmental science society? } \\
\text { 4. What is the total investment of China environmental science society in the expo? } \\
\text { 5. What indicators do you use to measure the success of the event ? }\end{array}$ \\
\hline \multirow{2}{*}{ Co-organizer } & $\begin{array}{l}\text { 1. Why Messe Muenchen Zhongmao co., ltd. is interested in hosting this event? } \\
\text { 2. What are the biggest difficulties and challenges for handling this event? }\end{array}$ \\
& $\begin{array}{l}\text { 3. What are the indicators used by your company to measure the success of the event? } \\
\text { scanning, QR code, RFID, beacon, or mobile phone? }\end{array}$ \\
\hline \multirow{2}{*}{ On-site service contractors } & $\begin{array}{l}\text { 1. What are the biggest difficulties and challenges in providing services to exhibitors? } \\
\text { 2. What are your expectations? }\end{array}$ \\
\hline
\end{tabular}

\section{B. Checklist Designed for The Observation of Green and Non-green Elements in The Venue}

The first step of design thinking is to define the challenge of a specific group of people. In order to help the students define the challenge to hold green event, students are asked to observe using all five senses on green and non-green elements in the venue, asking questions to the relevant stakeholders and experience the event from the perspective of $3 R$ principles, that is reduce, reuse and recycle. Observation checklist is designed for this purpose.

TABLE II. OBSERVATION CHECKLIST ON GREEN AND NON-GREEN ELEMENTS IN THE VENUE

\begin{tabular}{|c|c|}
\hline Experience perspective & Observation Checklist \\
\hline Venue & Record green and non-green element \\
\hline Stand construction & $\begin{array}{l}\text { 1) Is the building material reusable? } \\
\text { 2) Is the waste disposal fee included in the stand rental? } \\
\text { 3) Is there a recycling station in the exhibition hall? }\end{array}$ \\
\hline Stand design & $\begin{array}{l}\text { 1) How about the stand design? Economy, luxury or moderation? } \\
\text { 2) How about the stand personnel? Too many, too few or appropriate? } \\
\text { 3) How about the promotional materials? Hardcopy or softcopy? } \\
\text { 4) How about green and non-green elements on stand design? }\end{array}$ \\
\hline exhibitor & $\begin{array}{l}\text { 1) How many times has your company attended this exhibition? } \\
\text { 2) Have you ever attended a similar exhibition? } \\
\text { 3) What's the motivation for your company to attend the exhibition? } \\
\text { 4) What do you expect to achieve by attending the exhibition? } \\
\text { 5) How many people did your company send to attend the exhibition? } \\
\text { 6) Is your company a local/foreign company? } \\
\text { 7) How many days will the exhibitors stay in Shanghai? } \\
\text { 8) How large is your booth? } \\
\text { 9) Does your company support the green exhibition? } \\
\text { 10) What problems does your company encounter in the process of going green? Are you } \\
\text { satisfied with the green design and concept of the expo? }\end{array}$ \\
\hline visitor & $\begin{array}{l}\text { 1) What industry are you from? How many times did you attend the exhibition? Have you } \\
\text { ever attended a similar exhibition? } \\
\text { 2) Why did you come to the exhibition? } \\
\text { 3) What purpose do you expect to achieve? } \\
\text { 4) Do you attend the exhibition on your own or not? } \\
\text { 5) Where are you from? } \\
\text { 6) How many days are you going to stay in Shanghai? } \\
\text { 7) Have you ever used the APP of the event? }\end{array}$ \\
\hline
\end{tabular}

\section{DESIGN THINKING AS TEACHING-LEARNING METHODOLOGY}

Design thinking methodology has six phases: definition, research, interpretation, ideation, prototyping and evaluation. Teaching activity is implemented according to this process.[1][2]

\section{A. A Teaching Process to Cultivate Design Thinking Strategy}

When the students are back to the classroom from the exhibition venue, it is time that we start the second section of the course and experience design thinking process. First thing to do is to set up project teams. 70 students from two classes mixed together and were divided into 10 groups with 7 in each group. Event Model Canvas, the design thinking tools, is introduced and explained how it is applied in the event design process. The key point is to understand the pains thoughts and feelings, anything negative of stakeholders. At the same time, 
understand their expectations based on their previous experience, from social medial and marketing message. By doing the research, observation, asking the right questions, the students improved their contextual thinking skill.[4]

\section{B. A Learning Experience to Cultivate the Interpersonal Communication Skill}

Before working on the team project, the students should be quite clear about the requirement of the event simulation project. The purpose of this project is to allow students to design and plan a simulated exhibition using Event Model Canvas. Sustainable design and management should consider the concept of triple bottom line. Develop a sustainable management plan based on the concept. Think about how to reduce carbon footprint and 5R's of sustainable management: Refuse, reduce, reuse, and recycle and ROI. Think about some pressing issues related to events and define the challenges facing the industry.[5] The exhibition theme is 2028 Green Event. There are 10 groups and 7 students in each group. Each group chooses a forward-looking theme and develops solutions to the green issues and challenges that the 2028 exhibition may face. Each group designs a 3-meter-by-3-meter display booth model, which shall not exceed 1 meter-by-1meter. This model must be made of reusable and recyclable materials. If new materials are to be used, the cost of the newly purchased material shall not exceed 50 yuan. Besides, students should hand in planning report on group performance standards, project management plan including timelines, milestone, checkpoints and prototype for 2028 Green Event

Students start the group work brainstorming and experiencing the six phases of design thinking methodology with the help of the teachers. Design processes differ from scientific processes in their characteristic nature.[6] The first difference is the definition of the problem itself. Concretization and define the challenge of a specific group of people. Detect patterns among research data and use them to generate actionable interpretation. By using empathy map students have better understanding of the insights of the stakeholders.[7] Finally, each group developed and presented their green event solution prototype by creative thinking, visual thinking and critical thinking and was evaluated by the teachers and the judgers from the industry.

TABLE III. CHALLENGES AND SOLUTIONS FOR THE EVENT STAKEHOLDERS

\begin{tabular}{|c|c|c|c|}
\hline Group & Stakeholder & Challenges & Solutions \\
\hline A & Outdoors Explorer & Shortage of energy and drinking water & multifunction Eco-cycle Tend \\
\hline B & $\begin{array}{l}\text { Destination city } \\
\text { Or Community }\end{array}$ & $\begin{array}{l}\text { Urban traffic congestion, vehicle emissions } \\
\text { lead to urban air pollution }\end{array}$ & New modes of urban public transportation \\
\hline $\mathrm{C}$ & Organizer & $\begin{array}{l}\text { high cost, energy consumption and waste of } \\
\text { resources }\end{array}$ & Generator floor dance floor power \\
\hline $\mathrm{D}$ & exhibitor & $\begin{array}{l}\text { High transportation cost for regular drinking } \\
\qquad \text { water }\end{array}$ & Recycling of drinking cups \\
\hline $\mathrm{E}$ & venue & garbage disposal & $\begin{array}{l}\text { water reusing device and PET bottle recovery } \\
\text { device. }\end{array}$ \\
\hline $\mathrm{F}$ & Stand construction & construction waste disposal & $\begin{array}{l}\text { Reuse construction waste using 3D printing } \\
\text { technology }\end{array}$ \\
\hline G & exhibitor & $\begin{array}{c}\text { High cost and time-comsuming of disposable } \\
\text { disassembly treatment of the stage for brand } \\
\text { promotion activities }\end{array}$ & $\begin{array}{l}\text { To build green multi-functional reusable } \\
\text { circular stage theatre }\end{array}$ \\
\hline $\mathrm{H}$ & venue & $\begin{array}{l}\text { Waste disposal such as empty bottles or } \\
\text { waste paper board }\end{array}$ & $\begin{array}{c}\text { Collect and transform them into small artworks } \\
\text { or daily necessities as gifts to exhibitors and } \\
\text { visitors }\end{array}$ \\
\hline I & organizer & $\begin{array}{l}\text { How to save energy to hold a green } \\
\text { exhibition }\end{array}$ & $\begin{array}{l}\text { Energy conversion, Photovoltaic integrated } \\
\text { power generation system installed on the roof } \\
\text { of the venue and solar parking }\end{array}$ \\
\hline $\mathrm{J}$ & Exhibitor & $\begin{array}{l}\text { high cost for stand construction and stand } \\
\text { rental }\end{array}$ & $\begin{array}{l}\text { The venue provide stand design, set-up and } \\
\text { dismantle as well as rubbish disposal in order to } \\
\text { reduce the relevant cost for the exhibitors }\end{array}$ \\
\hline
\end{tabular}




\section{CONCLUSION}

The paper discusses the pedagogical methodology developed by applying the design process to the experiential education practices. We have students identify the problem before designing the solution, keeping projects open, encouraging students' team work, allowing students to develop strategic plans rather than a tactical plan and finally having students demonstrate their solution through prototype. This experimental teaching might cultivate students design thinking in three major aspects, which is cognitive, affective, and interpersonal communication.

A. Improve Cognitive Vision. Management education should ideally be concerned with 'what ought to be' in contrast to pure sciences which are concerned with explaining 'what is'. Design thinking includes inductive, deductive, and abductive reasoning. Abductive logic is the process of forming an explanatory hypothesis. It is the only logical operation which introduces any new idea. Design thinking, therefore, combines the generation of new ideas with their analysis and an evaluation of how they apply generally. It cultivates discovery skills which include questioning, observing, experimenting, networking, and associative thinking.

B. Change the Affective Attitude. Design attitude is concerned with finding the best answer possible, given the skills, time and resources of the team, and takes for granted that it will require the invention of new alternatives. In conventional management thinking, constraints are seen as an undesirable barrier to the generation and implementation of ideas; for a designer, however, constraints are embraced as the impetus to creative solutions. And as a creative process, it follows a mindset that is human-centered, action-oriented, prototype-driven and non-judgmental. Thus, it espouses positivity and eliminates the fear of failure and maximizing input and participation from the participants.

C. Encourage Interpersonal Communication. Emphasis on empathy with others is part of the design process A designer works with other people either by understanding stakeholders and their needs or by collaborating with peers. It cultivates exploratory learning which involves flexibility, discovery, and innovation, requiring an adaptive feedback model. Design Thinking has an impact on the way that the students engage in the learning process encouraging creativity and innovation and fosters collaboration as students are willing to listen, take risks and share ideas among peers.

Design thinking provides students opportunities to cycle through the processes of active experimentation, concrete experience, reflective observation and abstract conceptualization which form the cycle of effective learning. These are fundamental to conductive innovation education.

\section{ACKNOWLEDGMENT}

This research was supported by the Tourism Management Discipline Research Program funded by Shanghai Polytechnic University, P.R. China (Grant NO. XXKPY1607).

\section{REFERENCES}

[1] David Dunne, Roger Martin, Joseph L. Rotman, “ Design Thinking and How It Will Change Management Education:" An Interview and Discussion, Academy of Management Learning \& Education, Vol. 5, No. 4, PP 512-523, 2016.

[2] Travis J. Brown and Donald F. Kuratko, "The Impact of Design and Innovation on the Future of Education", Psychology of Aesthetics, Creativity, and the Arts, Vol. 9, No. 2, PP 147-151, 2015.

[3] Roy Glen, Christy Suciu, Christopher Baughn, "The Need for Design Thinking in Business Schools - A Review, Academy of Management Learning \& Education, Vol. 13, No. 4, PP 653-667., 2014.

[4] Brown, V. A., Harris, J. A., \& Russell, J. Y., “Tackling wicked problems through trans-disciplinary imagination. London, UK, Earthscan. (2010).

[5] Goldsby, M. G., Kuratko, D. F., \& Nelson, T. E., "Design centered entrepreneurship: A process for designing opportunities."Annals of entrepreneurship education and pedagogy, pp. 200-217, Edward Elgar Publishing, 2014.

[6] Hon, A. H., Bloom, M., \& Crant, J. M.," Overcoming resistance to change and enhancing creative performance. Journal of Management, 40, 919-941, 2014.

[7] Kuratko, D. F., Covin, J. G., \& Hornsby, J. S," Why implementing corporate innovation is so difficult." Business Horizons, 57, PP 647-655, 2014. 